\title{
Confucianism, the Idea of Min-pen, and Democracy
}

\author{
A. T. NUYEN
}

\section{Abstract}

With few exceptions, it is believed that Confucianism is incompatible with democracy. The 'incompatibility thesis' has attained the status of near orthodoxy. It is shared by commentators who are hostile as well as those sympathetic to Chinese culture generally and to Confucianism in particular. The arguments for incompatibility typically stress the differences between on the one hand 'democratic values' such as liberty, equality and plurality, and on the other 'Confucian values' such as duty, responsibility and loyalty. Having challenged the arguments for incompatibility by showing that the differences between so-called democratic values and Confucian values are in fact greatly exaggerated, the paper proceeds to discuss the significance of the Confucian idea of min-pen (or min-ben, people as roots). The aim is to show that philosophical Confucianism is not only not an obstacle to democracy but could well be the foundation thereof. The argument will then be further reinforced by revisiting the old 'modernization thesis.'

\section{Introduction}

Whether Confucianism can accommodate democracy is a question that impinges on many issues of East-West relationship. If Confucianism is incompatible with democracy, then for 
the West to demand the Confucian states to democratize is for it to run the risk of being accused of cultural imperialism. There is also a risk for the Confucian states themselves. Thus, given incompatibility, those states that choose to embrace democracy, perhaps to gain commercial favours such as membership of the World Trade Organization, run the risk of compromising, if not sacrificing, their cultural heritage.

On the other hand, if Confucianism is compatible with democracy, the West need not be intimidated by the charge of cultural imperialism in expressing its preference for the democratization of the Confucian states. As for the Confucian states themselves, given compatibility, they can embrace democracy without having to compromise their Confucian heritage, or even experiment with different forms of democracy to find one that allows Confucianism to flourish.

After nearly half a century of debate, commentators are still evenly divided on whether Confucianism is compatible with democracy. This paper is an attempt to add some weight to the case for compatibility. In the first section, I address some recent arguments for incompatibility. Thereafter I discuss the Confucian idea of min-pen (min-ben) and argue that Confucianism puts the emphasis on establishing what turns out to be the condition for true democracy. Finally, I combine the idea of min-pen with the 'modernization thesis' and argue that progress towards democracy may well be inevitable for a Confucian state that successfully implements the idea of min-pen.

\section{Against Incompatibility}

Those who hold the view that Confucianism and democracy are incompatible include commentators who are sympathetic as well as those who are unsympathetic to Confucianism. Among the unsympathetic commentators is Samuel P. Huntington, according to whom 'Confucian democracy' is a contradiction in terms in so far as Confucianism emphasizes 'the group over the individual, authority over liberty ... responsibilities over rights', and 'order and respect for hierarchy', and provides 'no 
legitimacy for autonomous social institutions.' (Huntington 1991: 24). Since democracy respects individual liberty and rights, including rights against the state, and autonomous social institutions separate from the state, it cannot be accommodated in any Confucian state. As a result, Confucian states are 'either undemocratic or antidemocratic'. These views are reinforced in Huntington's later and highly controversial book, The Clash of Civilizations and the Remaking of World Order. (Huntington 1996). There, he claims that '[D]emocratization was most successful in countries where Christian and Western influences were strong' (p. 193). By implication, it is the Confucian influences in the 'Sinic civilization' that act as an impediment to democratization. South Korea and Taiwan have made some progress only because the 'Christian leaders [there] promoted movement towards democracy' (p. 193).

It is not unreasonable to think that Huntington is articulating a view commonly held in the West. It will not do to reject this view on the grounds that it grows out of an unsympathetic perspective of Asia and its culture, or on the grounds that it is held by people who are not well enough informed about Asia. The reason is simply that it can also be found among wellinformed supporters and defenders of Asian culture. In his recent book, China's Transition (Nathan 1997), Andrew Nathan is optimistic about the prospects for democratization in China but still believes that Confucian influences make the process more difficult. The Confucian emphasis on social harmony is seen by Nathan as an obstacle to democracy because he takes it to be antithetical to the individual and the individual's rights, the recognition of which is a prerequisite for democracy. Thus, to make progress towards democracy, China has to grapple with the 'major issues of the Western tradition', i.e. issues involving 'rights [and the] individual' (p. 216). If there is a transition towards democracy in China, it will take place in spite of the Confucian culture. On this, Nathan is quite optimistic: The Confucian influences 'should not be taken to imply that Chinese political culture is inhospitable to democratization' (p. 285). Nathan believes that China is in the process of developing political and economic institutions that are capable of over- 
coming the adverse effects of Confucianism. In any case, Nathan argues that his empirical research shows that there is no longer a distinctive Confucian culture in the so-called Confucian states.

In contrast to Nathan, Chenyang $\mathrm{Li}$ is a well-informed defender of Confucianism. Still, he holds the view that Confucianism and democracy are incompatible, or more specifically, the view that Confucian values clash with democratic values ( $\mathrm{Li}$ 1999). There is here an echo of Huntington's 'clash of civilizations'. However, unlike Huntington, and like Nathan, Li is optimistic about the prospects for democracy in the Confucian states. But while Nathan suggests, as we have seen, that the Confucian influences must be overcome, or somehow 'grappled with', for there to be progress towards democratization, $\mathrm{Li}$ believes that the Confucian states need not sacrifice their Confucian heritage for the sake of democracy, even though the two are incompatible. The Confucian states can promote both Confucian values and democratic values. $\mathrm{Li}$ insists that the seemingly impossible feat of combining two incompatible sets of values is in fact possible. After all, Li points out, the Chinese have successfully embraced different religions, such as Buddhism, Taoism and Confucianism. That they can do so shows that they should be able successfully to embrace Confucianism and democracy as two distinct and incompatible value systems.

It is beyond the scope of this paper to challenge Li's argument that a Confucian state can embrace incompatible value systems. ${ }^{1}$ The aim in the discussion above is to show that, one way or another, the incompatibility of Confucianism and democracy is now almost an orthodoxy. Almost, because there are some notable exceptions. For example, Francis Fukuyama believes that Huntington's arguments 'overstate the obstacles that Confucianism poses to the spread of a political system that is recognizably democratic in a Western sense' (Fukuyama 1995: 25). Following Tu Wei-ming, Fukuyama makes a distinction between 'political Confucianism' and Confucianism as a 'personal ethic', a distinction that, as we shall see below, can also be found in other commentators. It is political Confucianism that 'legitimates a hierarchical political system' and sup- 
A. T. Nuyen

ports the 'bureaucracy of gentlemen-scholars' (p. 26). As a personal ethic, Confucianism emphasizes commitments to the 'family, work, education, and other elements of daily life' ( $p$. 26). These commitments are valued above any obligations to the state or to the emperor. Fukuyama concludes that 'Chinese Confucianism ... does not legitimate deference to the authority of an all-powerful state that leaves no scope for the development of an independent civil society' (p. 28), and that 'Confucianism by no means mandates an authoritarian political system' (p. 30). ${ }^{2}$

Another notable exception is Peter Berger. Berger traces the incompatibility thesis back to Weber. He recognizes that 'there is an argument (standing Weber on his head) that East Asian cultures (because of Confucianism or some other religio-ethical traditions) are peculiarly suited for modern development' (Berger 1986: 155). Among the Confucian 'values and attitudes', we find 'a highly developed sense of practicality or pragmatism, an active rather than contemplative orientation to life, great interest in material things ... and, last but not least, a great capacity for delayed gratification and discipline' (p. 163). These values and attitudes are conducive to 'modern development'. Confucianism also promotes political stability, which is also conducive to development. To be sure, the emphasis here is on economic development. However, Berger goes on to say that there is 'weak support for the thesis that successful capitalist development generates pressures towards democracy' (p. 161, emphasis in original). Berger points out that it was Weber himself who made a distinction between 'the vulgar [and] the "high" versions' of any set of ideas, and who suggested that it was the vulgar versions that would 'have the most historical efficacy' ( $p$. 101). This distinction parallels the Tu Wei-ming/Fukuyama distinction between 'political Confucianism' and philosophical Confucianism mentioned above. It is possible that in drawing our attention to Weber's distinction, Berger wants to say that it is the vulgar versions of Confucianism, or politicized Confucianism, that are responsible for the misconceptions about Confucianism and its relation to democracy. 
The exceptions we have found in Fukuyama and Berger are rare, rare enough not to challenge the near-orthodoxy status of the view that Confucianism and democracy are incompatible. I wish to add some weight to the challenge to this view. To do so, we need to formulate more systematically the case for incompatibility. Following Chenyang $\mathrm{Li}$, we can state the case for incompatibility as follows. There are certain values that serve as prerequisites for democracy, particularly the values of liberty, equality and pluralism. These values are incompatible with the Confucian values of duty, responsibility and loyalty.

First, the democratic value of liberty is grounded in the concept of individual rights. Since this concept conflicts with many fundamental Confucian tenets, liberty is incompatible with Confucianism. There appears to be no place for the concept of rights in Confucianism. It may be said that the Confucian society is like a family and there is no place for rights in a family. It may be said further that the idea of right is incompatible with the Confucian idea of jen. Jen requires the individual to exercise self-restraint, to attend to his or her duties and responsibilities determined by his or her position in the society, and to remain loyal. The person with jen cannot exercise full personal autonomy and so cannot be said to be in full possession of liberty.

Second, the democratic value of equality is incompatible with Confucianism. Notoriously, Confucianism specifies strict hierarchical roles. The doctrine of the three bonds requires the child to be obedient to parents, the wife to the husband and the subject to his or her sovereign. Equality is also incompatible with many Confucian ideals such as meritocracy and paternalism. While Confucianism accepts the idea of 'natural' equality, or the equality of natural attributes, it rejects the idea of 'evaluative' equality, or the equality of worth and therefore treatment. The Confucian idea of a sage or a gentleman (jun zi) implies that people are unequal, depending on where they are in the process of becoming a sage or a gentleman. As Chenyang Li puts it, to say that we are all of equal worth and deserve equal treatment is to 'undermine the Confucian ideal of "jun $z i$ " that is at its core.' (Li 1997: 177) Those who are regarded as able 
and wise are supposed to take care of the less able and wise, and so must have authority over the latter. All these Confucian ideals and values conflict with the democratic value of equality and its cognate values of individualism and autonomy.

Third, the Confucian values of unity and harmony conflict with the democratic values of plurality and choice. The latter, of course, are related to the democratic value of individualism. In privileging the social whole over individuals, Confucianism strives towards unity at the expense of plurality and choice.

I shall challenge the above arguments for incompatibility because I believe that the differences between Confucian and democratic values are greatly exaggerated.

Concerning rights, it may be said that rights must be upheld if certain Confucian ideals are to be obtained. For instance, the Confucian emphasis on responsibilities makes no sense in the absence of rights. It may be that in an ideal family or society, rights are not necessary but the progress towards that ideal may not be possible without rights. In practice, rights must be recognized even within the Confucian family. Daniel A. Bell has pointed out that in Han times, Confucian family values resulted in people having the right 'to conceal the crimes of close relatives' and the right not to 'testify in court against family members' (Bell 1999: 463). In the Ching dynasty, the parents' right of respect from children was protected by law. ${ }^{3}$ Also, it may be said that the Confucian ideal of $l i$ (propriety) implies the observance of rights-not individual rights generally but the rights of an individual in a certain social position. The impression that Confucianism has no notion of individual rights probably arises from the fact that there are no free-floating rights in Confucianism and that rights are embedded in social contexts. While there are no free-floating rights, it may be said that in the notion of $l i$ there is a recognition of rights attached to individuals in specific social positions.

What the supporters of the incompatibility thesis have in mind by 'individual rights' and liberty is perhaps the idea that each individual is free to act in his or her own interest without having to put group interests above individual interests. The 
problem here is that it is not clear how right and liberty understood in this way are crucial for democracy. Surely, there are limits to the pursuit of individual interests in any democracy, let alone a robust one. There are situations in a democracy when individual rights have to be sacrificed for the sake of group interests. Government authorities in Western democracies routinely appropriate private land for the construction of highways, conscript young men and women into the armed forces, prohibit the consumption of dangerous drugs, the reading and viewing of certain materials and so on. Leaders in Western democracies routinely call on citizens to sacrifice individual rights and interests; recall President Kennedy's famous exhortation: 'Ask not what your country can do for you. Ask what you can do for your country.'

It is true that Confucianism places a great deal of value on loyalty. However, the idea that loyalty is incompatible with liberty has to be challenged. Even if we accept that loyalty implies being bound to others, we can question the assertion that a loyal person is not really fully autonomous. I have given an account of the value of loyalty elsewhere (Nuyen 1999a). Suffice it to say here that one would appreciate the loyalty of a fully autonomous person and by the same token one would be very sceptical of the loyalty of a slave, if loyalty it is. On the other hand, it is wrong to think that loyalty has no place in democracy. While it is true that legislators in the United States of America often do not vote according to party lines, the situation is not quite the same in democracies based on the Westminster system. Party loyalty is taken much more seriously in places such as Britain and Australia. Furthermore, commentators such as Fukuyama and Bell have pointed out that the Confucian emphasis on loyalty acts as a limit on state authority and could well work against authoritarianism, not in favour of it as the 'incompatibilists' imagine. Indeed, Bell points out that in Imperial China, Confucianism was frequently 'criticized ... for encouraging disobedience and fostering a critical perspective vis-à-vis the state. Far from justifying blind adherence to the political status quo, Confucian values often provided the intellectual resources for social critics' (Bell 1999: 463). 
I turn now to the democratic value of equality, which is supposed to be incompatible with many key Confucian tenets. Granting that social roles defined in Confucianism implies inequality, it does not follow that Confucianism is incompatible with the idea of equality. What the 'incompatibilists' fail to notice is that there are two dimensions of equality. In the 'horizontal' dimension, equality means that equals have to be treated equally. In the 'vertical' dimension, it means that unequals have to be treated unequally. This structure of equality is enshrined in Aristotle's Nicomachean Ethics. That there is inequality in social roles does not mean there is no equality. Indeed, in so far as social roles are specified for unequals, equality requires unequal treatments of people in those social roles. That fathers and husbands should have greater authority over sons and wives is equality in its vertical dimension at work in so far as fathers and sons and husbands and wives are social unequals. Whether they should be, of course, is a different matter. In general, the very fact of roles implies inequality in rights and responsibilities. To assign a role to someone, no matter how humble, is to allow and expect that person to do certain things that we do not allow or expect other people to do. Inequality in roles is not inequality generally and it could well be just the vertical dimension of equality.

As for meritocracy and paternalism, there is no reason to think that they are incompatible with democracy. Indeed, modern Western democracies are capitalist in nature and capitalism actively promotes competition, hence meritocracy. On the other hand, many commentators regard the Chinese idea of meritocracy as conducive to equality. We saw above that Berger believes that many Confucian values positively contribute to economic progress, which in turn leads to greater economic equality. Also, Fukuyama claims that 'the traditional Confucian examination system was a meritocratic institution with potential egalitarian implications' (Fukuyama 1995: 25). Paternalism too should not impede progress towards democratization. Many Western democracies also have extensive welfare systems which tend to be paternalistic in conception and implementation. 
Finally, it is a mistake to think that Confucianism promotes unity at the expense of pluralism and that democracy emphasizes pluralism at the expense of unity. The idea of the 'one hundred flowers' actively promoted in Confucian times can be interpreted as a call for pluralism. Against this, it may be said that while Confucianism welcomes the plurality of ideas, it is against the idea of the plurality of social groups and factions. However, it is not clear how the plurality of ideas could flourish without plurality at the social level. It is more plausible to suppose that Confucianism is only against the kind of social division that works against the common interest. But then, which society would be in favour of it? Western democracies certainly do not promote plurality at the expense of social unity. Politically, the most robust democracies have evolved towards a two-party system rather than the kind of political pluralism that impedes the promotion of the common purpose, whatever that may be. Socially, we only have to remind ourselves of the American motto, e pluribus unum..

To be sure, in contemporary Western democracies, individualism and the idea of individual rights have been pursued much more vigorously than in any Confucian state. However, it can be said that they are pursued to the point where many undesirable consequences have emerged, which could threaten democracy itself. The cult of the individual is no reason to think that individual rights and liberty are fundamental democratic values. Indeed, leaders in many Western democracies have realized the detrimental effects of the cult of individualism and have called for a return to 'traditional' family values. The emphasis on the family is noticeable in recent political campaigns in America as well as Britain. In other democracies, notably Israel, there has always been a long tradition of putting the family and the community ahead of the individual. The Kibbutz in Israel embodies just such a tradition.

I have tried to show that the recent arguments for incompatibility can be challenged. This in itself does not prove that democracy is compatible with Confucianism, much less that a Confucian state is ipso facto democratic. The trouble is that historically, what Tu Wei-ming calls 'political Confucianism', or 
A. T. Nuyen

what Berger calls 'vulgar Confucianism', is the dominant form of Confucianism, if not the only one. The Confucian states that embody this form have been undemocratic, even antidemocratic. What we need to show is that there are resources within theoretical Confucianism, or 'high Confucianism' for Berger, that allow the development of a democratic state. In this regard, the most promising idea is that of min-pen (or min-ben): the concept that people are the foundation of government. A few commentators have acknowledged the democratic potential of this idea, such as Viren Murthy (Murthy 2000) and Chenyang Li. However, such commentators in the end argue that it is insufficient for the development of democracy. For Li, even if the country is governed according to min-pen, the government 'is at most "for the people"': it is questionable whether such government is ' "of the people" [and it is] clearly not "by the people"' (Li 1999: 170). Li may have seriously underestimated the significance of min-pen. It is worth tracing the development of this idea.

\section{The Idea of Min-pen}

To govern according to the idea of min-pen is to govern for the people (min), for their well-being, their prosperity and their security, thus tending to the people as one would tend to the roots (pen) of a tree. The emphasis on governing for the wellbeing and prosperity of the people can be found in the writings of Confucius (e.g. Analects 13.9). The idea of min-pen itself can be traced back to pre-Confucian times, but it receives a full treatment in the writings of key Confucians such as Mencius and Jia Yi. While Jia Yi perhaps articulates it more clearly than most, the key elements of min-pen are all there in Mencius.

For Mencius, the idea of min-pen implies the idea of pao min, or the protection of the people, protecting them against poverty and insecurity. As pointed out by Kung-chuan Hsiao, throughout 'the Seven Books of the Mencius, Mencius focuses his concern on enriching the people's livelihood, decreasing taxes and imposts, bringing wars to an end, and correcting bounda- 
ries' (Hsiao 1979: 150). Rulers are exhorted to ensure that people's livelihood is such that they have enough to look after their parents and their children (Mencius I, i, 7/21). Those who failed to enrich the people's livelihood were harshly condemned by Mencius. Only when people are prosperous can they be expected to behave morally, to have a 'constant heart' (Mencius III, i, 3). Two implications of Mencius's position are worth noting, given the earlier discussion in this paper. First, as pointed out by Hsiao (1979: 159), while the government has 'the absolute duty of nourishing the people and maintaining peace and stability', the people do not have 'any absolute duty of obedience to the government'. Second, again as Hsiao has noted, the 'ruler's relation to the people becomes in the last analysis one of equality', that is, 'possessing the right to respond in kind to the ruler's treatment of themselves [and thus standing] on the same footing with him'. Indeed, there are passages in the Mencius in which it is stated that the people are important and the ruler is unimportant (Mencius VII, ii, 14).

As pointed out earlier, the significance of the idea of min-pen has been dismissed by the 'incompatibilists'. For instance, on Chenyang Li's reading of Mencius, the latter's idea of min-pen 'does not exclude having a king as the sole decision-maker' and while the king 'might put his people's well-being first,' he might still act as a dictator ( $\mathrm{Li}$ 1999: 169-70). While this is logically possible, it is almost certainly not a possibility entertained by Mencius. A dictator acts only according to his or her wishes. It is possible that a dictator's wishes coincide with the people's wishes, but given the vast differences between the king and his people in terms of status, position, outlook and other circumstances, this is unlikely. What is more likely is that a king who puts his people's well-being first will have to compromise his personal interests. Indeed, that is what it means by putting someone else's interest first. Surely, min-pen does not mean putting the people's well-being first only when that happens to be in line with one's wishes, or when it serves one's own purposes. As stated above, min-pen means 'people as root (or foundation)'. In the case of the dictatorial king whose wishes just happen to coincide with the people's interests, the root or 
foundation of his government is still his wishes and the people cannot be said to be the root or foundation. Furthermore, for Mencius, the idea of min-pen is connected to the virtue of jen. It is unlikely that Mencius would entertain the idea of a dictator with jen. The king who puts the well-being of his people first is one with a benevolent mind (jen hsin) who is in charge of a benevolent government (jen cheng). (See for instance Mencius I, ii, 4 and II, i, 6.) Again, it is logically possible for there to be a benevolent dictator and perhaps there have been some in history, but there is no textual evidence to suggest that Mencius entertained this possibility.

Indeed, there is considerable evidence to suggest that Mencius believed that the people would be justified in deposing a dictatorial king who had lost the 'mandate of Heaven' (Mencius I, ii, 6). To be sure, this passage needs to be cautiously interpreted. For instance, Bell points out that it is 'possible to interpret this passage to mean that [the king] deserved to have his head cut off not because he didn't serve the people but because he was a bad person in a way that mattered to Mencius' (Bell 1999: 488n.). Bell goes on to say that the people 'may not have been the source of legitimacy in Mencius, but only its beneficiary and perhaps an operational indicator of its presence or absence'. The call for interpretive caution is welcome. For to say that Mencius always advocates putting the well-being of the people first may be going too far, as there are passages in The Mencius where he seems to assert the supremacy of the ruler. But equally, it is going too far to dismiss out of hand the significance of the idea of min-pen, as, for instance, Chenyang $\mathrm{Li}$ has done. Thus, $\mathrm{Li}$ argues that Mencius can only be talking about a 'moral approval of a rebellion' not 'a right to rebel' (Li 1999: 170). Li's point is that unless there is a right, written in law, for the people to dismiss a government of whom they disapprove, we do not have a government of the people and by the people, hence there is no democracy.

It has to be admitted that if democracy is strictly defined in terms of the people directly choosing the government, then the idea of min-pen falls far short of what is required for democracy. However, it comes much closer to it than commentators such as 
Li would have us believe. The idea of min-pen cannot be understood in isolation from political ideas such as the 'mandate of Heaven' and the practice of selecting government officials by public examinations. Combined with the idea of the 'mandate of Heaven', the picture that emerges is one in which the people do play a role in choosing the government, albeit indirectly, via Heaven. The people express their wishes and Heaven translates them into a mandate to be given to an appropriate government (Mencius V, i, 5). In this way, the mandate of Heaven just is the mandate of the people, and to lose the mandate of Heaven just is to lose the trust of the people. The people do have the right to choose, albeit not a right written in the law of man: it is a right written in the law of Heaven, or the law of the Tao. Thus, what we have in the ideas of min-pen and the mandate of Heaven is a government of the people (in so far as it is one that reflects their preference), for the people (in so far as it serves the people's well-being) and indirectly by the people, via Heaven. It is the last characteristic that technically differentiates it from a democratic government in the technical sense in which the people directly elect the government. However, it may be argued that direct election is not an end in itself but rather a means of choosing government officials in a fair, public and open way. If so then the fair, public and open examinations advocated by Confucianism conducted in Imperial China came closer to capturing the essence of democracy than the 'incompatibilists' believe.

On the other hand, it may be asked: How important is the technical requirement of direct election? In their report on human development in South Asia, Mahbub ul Haq and Khadja Haq (Haq and Haq 1998) argue that there is no true democracy in South Asia despite the fact that the peoples of South Asia can directly elect their governments. According to the authors, this is so because 'democracy' in South Asia is about access to state power and not about the people. Once in power, officials line their own pockets rather than govern for the people. Through corruption and mismanagement, South Asian governments have failed to provide their peoples with freedom from the worst kind of deprivation, namely poverty. It is interesting to 
note that the recent overthrow of the democratically elected government in Pakistan was greeted with general approval by the people, particularly when the extent of corruption and mismanagement was revealed.

By contrast, Mencius and other Confucians strenuously stress the importance of putting the people first and bringing about the elimination of poverty. As we have seen, for Mencius, minpen means to ensure that the people are prosperous. If the Haqs are right, direct election without min-pen produces a government democratic only in name. Their report shows that the true foundation of democracy is the prosperity of the people, not the technically democratic institutions. It may also be said that choices are meaningful only if they are informed and not made under pressure. Only prosperity will allow people to educate themselves and to choose without pressure. Only a government that governs with the idea of min-pen can ensure prosperity.

On the other hand, it has to be admitted that min-pen without direct election is not democracy, at least in the technical, Western sense. However, if the 'modernization thesis' is correct, prosperity inevitably leads to, if not democracy as we know it, then something close to it, close enough to be effectively democratic.

\section{Min-pen and the 'Modernization Thesis'}

The modernization thesis was first espoused by Seymour Martin Lipset in 1959. Lipset observed that there was a strong correlation between economic progress and progress towards democratization. As a country develops economically, authoritarianism tends to be replaced by democracy. The most economically advanced countries are also the most robust democracies. This correlation leads Lipset to the conclusion that economic development is not only the requisite of democracy, it could well bring about democracy. Is there any empirical evidence for this? As pointed out earlier, Peter Berger believes that the data he has collected provide.'weak support for the thesis that successful capitalist development generates pressures toward democracy' (Berger 1986: 161. Italics in the original). Reviewing 
more recent empirical evidence, Francis Fukuyama, in the article cited earlier, suggests that the modernization theory 'is more valid today than it was when it was first enunciated' (Fukuyama 1995: 21). However, for this thesis to have a theoretical basis, we have to come up with a plausible causal mechanism linking economic development to democratization. Fukuyama has suggested one such mechanism. He writes:

Economic modernization raises living and educational standards and liberates people from a certain kind of fear brought on by life close to the subsistence level. This permits people to pursue a broader range of goals, including those that remained latent in their earlier stages of economic development. Among those latent urges is the desire to be recognized as an adult with a certain basic human dignity-a recognition that is achieved through participation in the political system (Fukuyama 1995: 22).

Fukuyama has identified a powerful non-economic causal mechanism, namely the 'noneconomic desire for "recognition"' (p. 22). However, it would be too hasty to dismiss economic and other factors from the causal mechanism in view of the fact that there is a close relationship between the economic sphere, the institutional sphere and the political sphere. The 'desire for recognition' mentioned by Fukuyama could well have an economic motivation. As the people become more prosperous, they will increasingly become aware that their hard-won prosperity can be adversely affected by political decisions. As the economic stake gets bigger with economic development, there will be a greater desire to participate in the political process to ensure that political decisions help rather than hinder economic development. Confucians such as Mencius were fully aware of the desire for a political change when economic conditions were dire, when the people were threatened with starvation, when there was little to lose and much to gain in rebelling against the government. They did not realize that their argument could be extended to apply at the other end of the economic spectrum where the people enjoy economic prosperity and do not want to take their chances with an uncontrolled and unpredictable political system. People want to 
rebel when there is little to lose but they also want to rebel when there is much to lose.

In addition to the 'd'esire/for recognition', economic as well as non-economic, there are othér causal mechanisms at work. Indeed, if the desire/for recognition is the only mechanism at work, one may well wonder if commentators such as Chenyang $\mathrm{Li}$ are right after all in expressing the concern that democracy might compromise Confucian values. As we have seen, Fukuyama speaks of the desire 'to be recognized as an adult with a certain basic human dignity'. This is close enough to the desire for individual rights to be recognized and exercised, or the desire to express one's individualism. Within the modernization theory prosperity allows just the kind of trade-off that Confucians are reluctant to make. Thus, to defend the compatibility between Confucianism and democracy, we need to supplement Fukuyama's causal mechanism in such a way that the kind of democracy that follows economic progress is one that preserves Confucian values. The economic motivation suggested above works not through the desire for personal recognition but through the desire for consolidating and furthering the collective well-being of the entire people. Arguably, it is this rather than the non-economic motivation for personal recognition that is more in keeping with Confucian values.

More importantly, the causal mechanism suggested by Fukuyama, even when supplemented with an economic motivation, is by itself insufficient to account for the modernization theory. Undoubtedly, economic prosperity will bring about a desire, or stronger still a demand, for direct participation in the political process for both non-economic and economic reasons. But just because there is a desire, or a demand, it does not follow that the desire will be satisfied, or that the demand will be met. We still need to explain how economic progress will enable such a desire to be satisfied, or such a demand to be met. The explanation can be found in the necessary linkage between economic progress and the legal and political framework. Without a particular kind of legal and political framework, a country can only go so far in the process towards economic prosperity. If modern economic theory is correct, economic development 
depends on a legal and political framework that facilitates competition and minimizes business uncertainty.

The economy cannot develop unless the rule of law replaces the arbitrary rules of an authoritarian government. If the government is concerned about improving the livelihood of the people, then at some stage it will have to set up a suitable legal framework in which certain rights are recognized, such as the right to the profits earned through commercial effort. As the economy develops, the legal framework will have to be more and more extensive. More and more rights will become entrenched. What is required is what S. Gordon Redding (1998) calls the 'thickening' of civil society. I suggest that it is this 'thickened' framework that will allow the desire for political participation to be satisfied. Given that a dictator is benevolent and puts the interest of his or her people first, such a dictator will have to be less and less dictatorial if his or her benevolent desire to benefit the people is to be fulfilled. The benevolent dictator will be painted into a corner by the legal system that he or she must institute in order to ensure economic development. It is in this way that the modernization theory works out in practice.

The economic and institutional considerations above bring into the picture another element that has to be weighed against Confucianism, namely the nature of modern capitalism. The coupling of the idea of min-pen with the modernization theory will work in the way intended only if Confucianism is compatible with capitalism. On this score, there are also commentators who argue against compatibility. If they are right and if modern capitalism is the only way to economic prosperity (which seems to be the case, given recent economic history), then the idea of min-pen together with the modernization thesis spell disaster for Confucianism and Confucian values. In so far as min-pen is Confucian, it seems that the success of Confucianism in improving the livelihood of the people through the modern capitalist ways will bring about its demise. Fortunately, against these commentators, it can be shown, as I have done elsewhere (Nuyen 1999b), that Confucianism is compatible with capitalism. Indeed, Peter Berger goes further and suggests that 
in so far as values such as innovativeness, self-discipline, etc. are necessary for successful capitalist development, '(S)pecific elements of East Asian civilization, be it in the "great traditions" or in folk culture, have fostered these values and have consequently given the societies of the region a comparative advantage in the modernization process' (Berger 1986: 166, italics in original). As it turns out, the view that Confucianism and capitalism are compatible strengthens the view that Confucianism and democracy are compatible. Indeed, it gives credence to the view that the Confucian state that succeeds in its aim of serving the people's interest will be democratic.

Why, then, did Mencius and other Confucians not make the leap and argue for democracy? Why is it that, as Hsiao puts it, 'the principle of "by the people", and the institutions necessary to it, were things of which [Mencius] had never heard?' (Hsiao 1979: 161). The task of answering these questions is something I happily leave to the historians. I suspect, though, that it has to do with Chinese cosmology and metaphysics as well as the absence of modern economic conditions. The Chinese belief and strong faith in the operations of the Tao were such that the mandate of Heaven was as good as the mandate of the people, and that government by Heaven was practically the same thing as government by the people. It is also possible that economic conditions were such that even a thoroughly undemocratic government could manage to achieve prosperity for the people. After all, imperial Germany and Meiji Japan managed impressive economic achievements while being thoroughly undemocratic. However, it is unlikely that any authoritarian state could manage it under modern business conditions. Indeed, Bernstein, Berger and Godsell, having made the observation about imperial Germany and Meiji Japan, go on to state that 'authoritarian regimes rarely meet the conditions under which business can optimally flourish' (Bernstein et al. 1997: 6). If it were possible for imperial China to have economic prosperity without democracy in the modern sense, then there would be no need to make the connection between the idea of min-pen and democracy in the modern sense. We cannot expect Mencius or anyone else to make the theoretical leap without the need to 
jump. After all, the West made the jump only quite recently. The idea that one person, black or white, man or woman, is entitled to one vote became entrenched in the mindset of the West only in the 20th century.

\section{Conclusion}

If I am right in my various arguments above, in the present context, an elected government that governs without the idea of min-pen is not truly democratic and one that governs with the idea of min-pen and does so successfully will inevitably become democratic if it is not already so. From this, a number of implications for East-West relationship can be drawn. First, if the West is concerned about the elimination of poverty in Asia and elsewhere, it should focus on the implementation of the idea of min-pen in these regions rather than being concerned about whether there is democracy in the technical sense. The best policy with respect to a Confucian state committed to minpen could well be to let the progress towards democracy take its own course, to let things be, to 'take no action' (wu wei). Second, defenders of traditional Confucian values should not be sceptical of democratic values and the ways of modern capitalism. The worst features of democracy in the West, e.g. rampant individualism, lack of commitment to family and community, are not the requisites of democracy nor its inevitable consequences. The West should not think that democratization is the panacea and should be aware that democracy can be humbug. The East, in turn, should not think that democracy is a bugbear. $^{5}$

A. T. Nuyen received his Ph.D. from the University of Queensland, Australia. He has published widely on the philosophy of Hume and Kant, ethics and Continental philosophy. His works have appeared in international journals such as Hume Studies, Kant-Studien, History of Philosophy Quarterly, American Philosophical Quarterly, etc. Recently, he has developed an interest in comparative philosophy and has published in Asian Philosophy and the Journal 
A. T. Nuyen

of Chinese Philosophy. In January 2001, he became Associate Professor of Philosophy at the National University of Singapore. Prior to that, he was Reader in Philosophy at the University of Queensland. E-mail: nuyen@arts.uq.edu.au

\section{Notes}

1. It may be asked if Li's religious model is an appropriate one. Li himself admits that multiple religious participation is possible because the Chinese understanding of religion is flexible enough to include the social dimension and because the social domain itself is wide enough to have many different aspects in which different beliefs can be accommodated. But how do we flexibly understand democratic and Confucian values? The domain in which these values are exhibited seems too small to accommodate incompatible systems. Indeed, at the narrow, institutional level, there is very little room for manoeuvre and $\mathrm{Li}$ is forced to bite the bullet and admit that there is no question that China has to make its institutions democratic: 'The future social institution in China must be democratic.' (Li 1999: 184-185).

2. As one would expect, 'political Confucianism' had been criticized by Confucian scholars and philosophical Confucianism had been criticized by thinkers with political interests. Thus, the 17th-century Confucian scholar Huang Zongxi criticized the despotic appropriation of Confucianism in his Waiting for the Dawn: A Plan for the Prince (Huang 1993). On the other hand, Han Fei Tzu criticized Confucian scholars for fostering disobedience to the state.

3. It is interesting to find Chenyang Li drawing our attention to a story in the People's Daily of 25 August 1993, which reported that an old widow took her two sons to court for failing to look after her and that the court ruled in her favour (Li 1999: 127). What Li wants to say is that the idea of filial duty is still important in China today, but surely the story illustrates at least equally the importance of rights, in this case the right of the woman to be looked after by her sons. The ruling of the court could be interpreted as establishing this to be not just a moral right but a legal right as well.

4. All references to the Analects and The Mencius are found in the English translations by D. C. Lau (Lau 1970, 1979).

5. I wish to thank an anonymous referee for many helpful comments and suggestions. 


\section{References}

Bell, Daniel A. 1999. 'Democracy with Chinese Characteristics: A Political Proposal for the Post-Communist Era'. Philosophy East and West 49: 45191.

Berger, Peter L. 1986. The Capitalist Revolution. New York: Basic Books.

Bernstein, Ann, Peter L. Berger and Bobby Godsell 1997. 'Introduction: Business and Democracy: Cohabitation or Contradiction?'. In Ann Bernstein and Peter L. Berger (eds), Business and Democracy. London and Washington: Pinter, pp. 1-34.

Fukuyama, Francis 1995. 'Confucianism and Democracy'. Journal of Democracy 6: 20-33.

Haq, Mahbub ul and Khadija Haq 1998. Human Development in South Asia. Karachi: Oxford University Press.

Hsiao, Kung-chuan 1979. A History of Chinese Political Thought. Vol. One: From the Beginnings to the Sixth Century A.D. Trans. F. W. Mote. Princeton: Princeton University Press.

Huang Zongxi 1993. Waiting for the Dawn: A Plan for the Prince. Trans. Wm. Theodore de Bary. New York: Columbia University Press.

Huntington, Samuel P. 1991. 'Democracy's Third Wave'. Journal of Democracy 2: $15-26$.

1996. The Clash of Civilizations and the Remaking of World Order. New York: Simon \& Schuster.

Lau, D. C. (ed. and trans.) 1970. The Mencius. London: Penguin.

- (1979) (ed. and trans.) The Analects. London: Penguin.

Li, Chenyang 1997. The Tao Encounters the West. Albany: State University of New York Press.

Lipset, Seymour Martin 1959. 'Some Social Requisites of Democracy: Economic Development and Political Legitimacy'. American Political Science Review 53: 69-105.

Murthy, Viren 2000. 'The Democratic Potential of Confucian Minben Thought'. Asian Philosophy 10: 33-47.

Nathan, Andrew J. 1997. China's Transition. New York: Columbia University Press.

Nuyen, A. T. 1999a. 'The Value of Loyalty'. Philosophical Papers 28: 25-36.

- 1999b. 'Chinese Philosophy and Western Capitalism'. Asian Philosophy 9: 71-79.

Redding, S. Gordon 1998. 'The Impact of Multinationals on the "Thickening" of Civil Society: Current Developments in the Economy of China'. In Ann Bernstein and Peter L. Berger (eds) Business and Democracy. London and Washington: Pinter, pp. 93-106. 